Int. J. Morphol.,

34(3):909-917, 2016.

\title{
Macroanatomy of the Bones of Thoracic Limb of an Asian Elephant (Elephas maximus)
}

\author{
Macroanatomía de los Huesos del Miembro Torácico de un Elefante Asiático (Elephas maximus)
}

\author{
A. S. M. Lutful Ahasan*; Md. Abul Quasem*; Mohammad Lutfur Rahman*; \\ Rubyath Binte Hasan*; A. S. M. Golam Kibria* \& Subrata Kumar Shil*
}

AHASAN, A. M. S. L.; QUASEM, M. A.; RAHMAN, M. L.; HASAN, R. B.; KIBRIA, A. S. M. G. \& SHIL, S. K. Macroanatomy of the bones of thoracic limb of an Asian Elephant (Elephas maximus). Int. J. Morphol., 34(3):909-917, 2016.

SUMMARY: Bones of forelimb were studied from a prepared skeleton of an adult female Asian elephant (Elephas maximus) in Anatomy Museum of Chittagong Veterinary and Animal Sciences University to understand the morphological form and structure of Asian elephant forelimb. The angle was approximately $123^{\circ}$ between caudal border of scapula and caudal border of humerus. The scapula, humerus and bones of the antebrachium (particularly the ulna) were massive bones. The bones of manus were the short and relatively small. The dorsal border of scapula extended from the level of proximal extremity of first rib to the middle of the $6^{\text {th }}$ rib. Ventral angle of scapula articulated with humerus by elongated shaped glenoid cavity (cavitas glenoidalis) of scapula and head of humerus (caput humeri). The major tubercle (tuberculum majus) of humerus was situated laterally to the head, which had smaller cranial part with large caudal part and extended cranially to the head. The crest of minor tubercle (tuberculum minus) was present as the rough line on the mediocaudal surface of humerus that ends in a slight depressed or elevated area, known as teres major tuberosity (tuberositas teres major). The lateral supracondyler crest (crista supra condylaris lateralis) at the caudal surface of the shaft limit the musculo-spiral groove in body of humerus. The radius and ulna are twin bones of forearm and the attachment between ulna and radius occurs in such a way, the radius articulates craniomedially with the ulna in the proximal part. But the shaft spirals laterally over the cranial surface of the ulna to articulate distally with the medial aspect of the ulna. There were 8 carpal bones, 5 metacarpal bones and 5 digits. The comparative size of the proximal and distal raw of carpal bones were ulnar carpal $>$ radial > intermediate > accessory carpal and IV > III > II > I respectively. The gradual lengths of the metacarpal bones were III > IV > II > V > I. Digits I and V were vertical and digit II, III and IV were horizontal.

KEY WORDS: Elephas maximus; Scapula; Humerus; Radius; Ulna; Manus.

\section{INTRODUCTION}

The elephant under the order of Proboscidea is a nonruminant herbivore, belonging to the family with two living genera and species of elephants, Elephas maximus, of Southern Asia and Loxodonta africana, of Africa (Nowak, 1999). Their habitat, primarily the tropical forests and grasslands (Keele \& Lewis, 2005) favored for their diet (especially leaves and grass) but slow digestion due to fast ingesta passage rates (Clauss et al., 2003) although the digestion abilities of elephants resembles that of horses.

The elephant appendicular skeleton; the fore and hind limbs are arranged in an almost vertical position under the body, similar to a pillar or leg of a table rather than being in the angular position seen in many other quadruped mammals to support great weight. Although elephants can walk, run and swim, they do not trot, canter, gallop and jump. Elephant can move slowly to quite fast, and elephants can out run most humans and can remain standing for long periods with the support of bones and limbs. Both in structure and in kinematic patterns (Muybridge, 1899; Howell, 1944; Gambaryan \& Hardin, 1974; Hildebrand \& Hurley, 1985; Hutchinson et al., 2003; Weissengruber \& Forstenpointner, 2004; Weissengruber et al., 2006) the limbs of elephants reveal many peculiarities. A column-shaped, extended limb integrates all structures of the locomotor apparatus (Howell; Gambaryan \& Hardin). Maximum body weight is supported by the larger forelimbs (60\%) (Alexander et al., 1979), the hind limbs are also well-matched to weight bearing (Weissengruber \& Forstenpointner). The shoulder, elbow and wrist joints of elephant are stacked one above the other to hold up its heavy bulk similar to an architectural column; the downward scapula is in line with the stout humerus and ulna. The reduced radius facilitate ulna to carry most of the weight. 
Like human foot, the carpals/tarsals and metapodials are set to form an arch, and the comprehensive and concise anatomical data on toes with their structures are still need to more study. The foot pad gives an analogous cushions comparable with the foot/heel pads in humans (Tietze, 1921). The short and robust metacarpals with phalanges make cushion in their forefoot having a pad of fat and skin. So, there is very little abduction of five metacarpal bones from the carpus that makes their position and articulation is different from other ungulates (Mariappa, 1986). There is a prepollux reaching from the carpal bone I to the pad, medial of the midline and probably stabilizing the carpus over the digital cushion. There is specific spreading of digits that direct to floor with their apices in an oblique inclined manner but the digit one D-1 and D-5 stand steep (Virchow, 1910) that is also applicable for the hind foot. So the aim of this study was to elucidate the gross anatomical outline of forelimb bones of Asian elephant and to contribute in the field of radiological and forensic studies.

Table I. Measurement data on various features/ forms and structures of Asian Elephant forelimb bones.

\begin{tabular}{|c|c|c|c|}
\hline $\begin{array}{l}\text { Forelimb } \\
\text { bones }\end{array}$ & Measurement of various forelimb bones features/ forms and structures & $\begin{array}{l}\text { Unit } \\
\text { (cm) }\end{array}$ & $\begin{array}{c}\text { Total weight } \\
\text { (Kg) }\end{array}$ \\
\hline \multirow[t]{12}{*}{ Scapula } & & & 3.4 \\
\hline & Maximum length (Margo dorsalis to cavitas glenoidalis) & 56 & \\
\hline & Maximum width from cranial border to caudal angle at costal surface & 40 & \\
\hline & Length of caudal border of scapula & 36 & \\
\hline & Length of dorsal border of scapula & 54 & \\
\hline & Length of cranial border of scapula & 59 & \\
\hline & Length of cavitas glenoidalis & 14 & \\
\hline & Width of cavitas glenoidalis & 8 & \\
\hline & Depth of fossa supraspinata & 9 & \\
\hline & Depth of fossa infraspinata & 11 & \\
\hline & Depth of fossa subscapularis & 4 & \\
\hline & Angle of scapula and humerus & 55 & \\
\hline \multirow[t]{11}{*}{ Humerus } & & & 5.4 \\
\hline & Circumference of proximal end of humerus & 60 & \\
\hline & Circumference of distal end of humerus & 54 & \\
\hline & Circumference at mid of diaphysis of humerus & 28 & \\
\hline & Circumference at neck of humerus at its proximal part & 47 & \\
\hline & Circumference at neck of humerus at its distal part & 53 & \\
\hline & Length of proximal articular surface of humerus & 15 & \\
\hline & Width of proximal articular surface of humerus & 11 & \\
\hline & Length of distal articular surface of humerus & 16 & \\
\hline & Width of distal articular surface of humerus & 12 & \\
\hline & Total length of humerus & 71 & \\
\hline \multirow[t]{7}{*}{ Radius } & & & 0.9 \\
\hline & Total length & 55 & \\
\hline & Circumference at proximal end & 21 & \\
\hline & Width at neck at proximal end & 13 & \\
\hline & Circumference at distal end & 32 & \\
\hline & Width at neck at distal end & 23 & \\
\hline & Circumference at the mid of the shaft & 14.5 & \\
\hline \multirow[t]{10}{*}{ Ulna } & & & 3.4 \\
\hline & Total length of Ulna & 64 & \\
\hline & Circumference of proximal end of ulna & 53 & \\
\hline & Circumference of distal end of ulna & 35 & \\
\hline & Length of Olecranon & 11 & \\
\hline & Circumference at distal end of olecranon & 42 & \\
\hline & Length of articular surface at distal end & 16 & \\
\hline & Width of articular surface at distal end & 7.5 & \\
\hline & Length of articular surface at proximal end & 9 & \\
\hline & Width of articular surface at proximal end & 16.5 & \\
\hline
\end{tabular}




\section{MATERIAL AND METHOD}

The forelimb bones of an adult female Asian elephant (Elephas maximus) were examined from a prepared skeleton placed in Anatomy Museum of Chittagong Veterinary and Animal Sciences University. This elephant died due to dystocia and the bones were collected from the deep burial with aseptic measure from Dulahazra Bangabandhu Safari Park, Cox's Bazar, Bangladesh. The bones were collected in a sequential manner, processed by removing the mud with brush and washed under running tap water, followed by dipping in detergent water for 2 hours. After removing the dirt, it was dried in sunlight for seven days. Whole processing was done carefully to keep anatomical feature unaffected. To get the anatomical parameter different views of each bone were observed. For gross biometric study, length, width and circumference were measured by using metallic scale and were recorded in centimeter. Weight was measured using a scientific balance. Angle between caudal margin of scapula and caudal margin of humerus was determined by a protractor placed on an angle of trigon drawn on a white paper by using the exact measurement of the length of caudal margin of scapula $(33 \mathrm{~cm})$, length of caudal margin of humerus $(55 \mathrm{~cm})$ and the distance between the caudal angle of scapula to the distal end of humerus $(78 \mathrm{~cm})$.

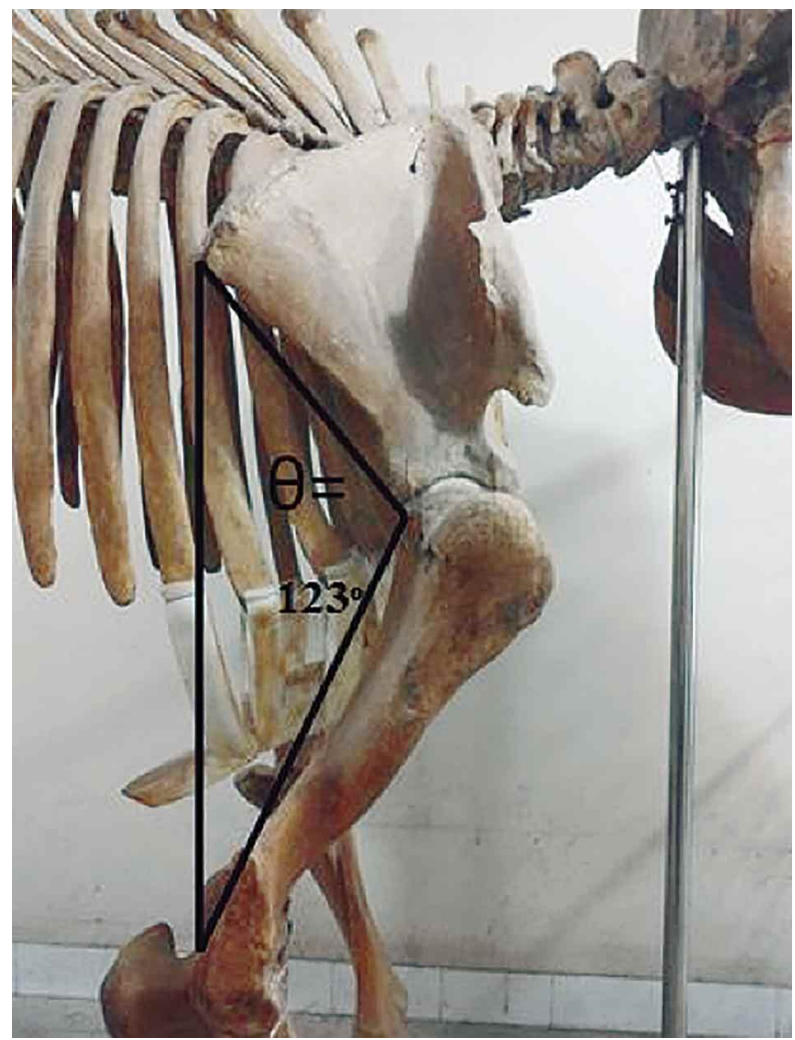

Fig. 1. Angle between caudal margin of scapula and humerus (Brachium).

\section{RESULTS AND DISCUSSION}

To maintain the heavy weight of body, there is a vertical architectural column like stalked made by the joining of elephant's shoulder, elbow and wrist (Grzimek, 1987). Broad scapula articulates with the humerus with an angle of $123^{\circ}$ to bear the body weight (Fig. 1). The ulna associates with the radius for carrying most of the body weight of elephant. The metacarpal and phalanges are short and robust. Measurement data on various features/ forms and structures of forelimb bones of Asian elephant are illustrated in Table I.

Scapula (Figs. 2-4). The scapula is a triangular flat bone situated in cranio-lateral aspect of the thorax with relatively wider at the dorsal end and narrow at the ventral end. It was slope slightly that help to adapt to the form of the thoracic limb laterally. The scapula of Asian elephant in the present study has been represented three margins, three angles and two surfaces which were found to be similar to those of the horse (Sisson et al., 1975), cattle (McLeod et al., 1958), sheep (Sisson et al.), lion (Nzalak et al., 2010) and dog (Miller et al., 1964). Its dorsal margin extends from the level of proximal extremity of first rib to the middle of the 6th rib. Scapular cartilage was found was present but was lost during the collection of specimen. A slight angular prominence (margo dorsalis) is formed at the level of scapular spine which divides the dorsal margin into very

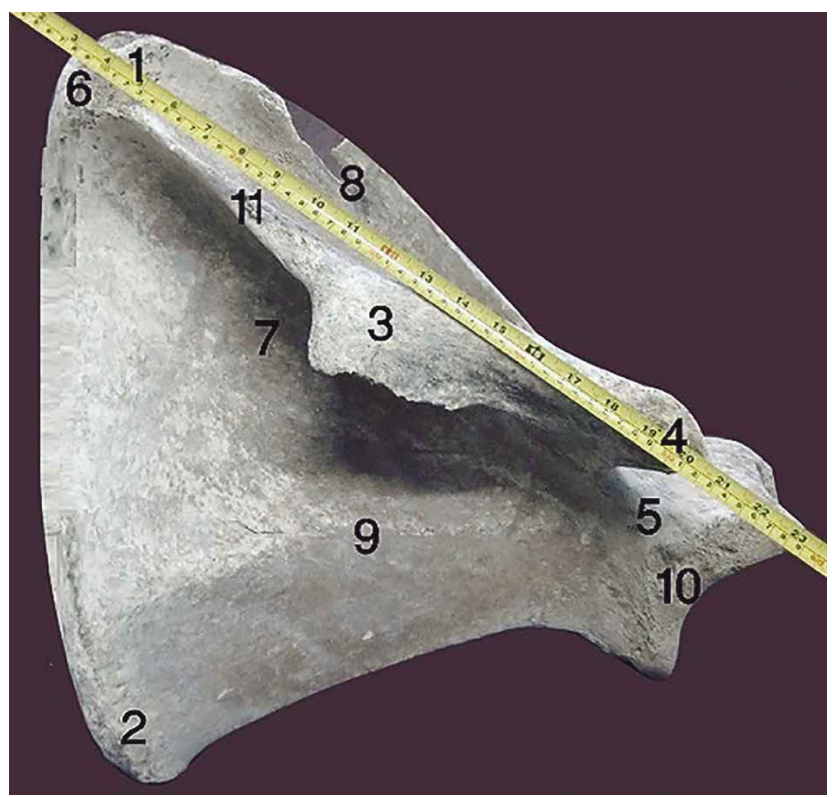

Fig. 2. Lateral aspect of right scapula. 1= Cranial angle (Angulus cranialis), 2= Caudal Angle (Angulus caudalis), $3=$ Processus suprahamatus, 4= Processus hamatus, 5= Ventral angle (Angulus ventralis), $6=$ Margo dorsalis, $7=$ Infraspinous fossa (Fossa Infraspinata), $8=$ Supraspinous fossa (Fossa supraspinata), $9=$ Muscular ridge, 10= Glenoid notch, 11= Spina scapulae (Scapular spine $)$. 


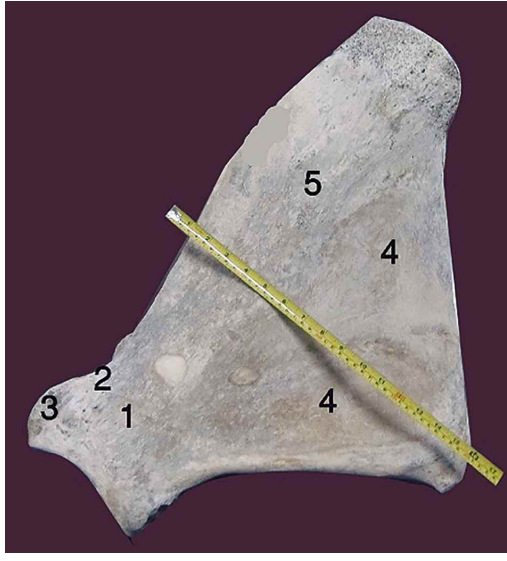

Fig. 3. Medial aspect of right scapula. 1= Scapular collar (Collum scapulae), $2=$ Incisura scapulae, $3=$ Supraglenoid tubercle (Tuberculum supraglenoidalis), $4=$ Cranial and caudal subscapular fossa (Fossa subscapularis) and 5= Facies serrata.

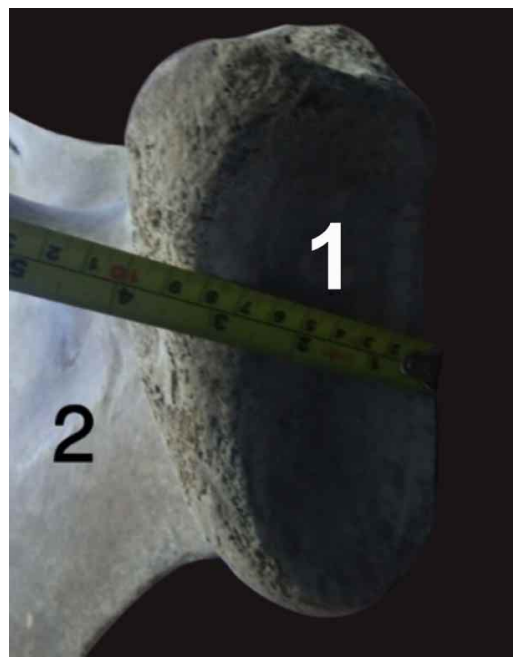

Fig. 4. Ventral angle of scapula. 1= Cavitas glenoidalis (Glenoid cavity) and $2=$ Muscular ridge.

shorter cranial part towards the cranial angle (angulus cranialis) and a longer rounder caudal part towards the caudal angle (angulus caudalis). But in African elephant, cranial part of dorsal margin is somewhat longer (Smuts \& Bezuidenhout, 1993).

Lateral surface of scapula . The prominent scapular spine (spina scapulae) divides the lateral surface into a smaller, smooth and elongated supraspinous fossa (fossa supraspinata) and a larger concave infraspinous fossa (fossa infraspinata) accompanies the most of the triangle. Here a distal continuation of the scapular spine namely acromion process or processus hamatus as like as cattle (McLeod et al.; Sisson et al.), which was thick, pointed and was not over hanged to the glenoid notch. However, the acromion was over hanged to the glenoid notch in human (Williams, 1980), Lion (Nzalak et al.) and African elephant (Smuts \& Bezuidenhout). At the level of scapular collar (collum scapulae), the scapular notch is formed by the cranial margin namely incisura scapulae. The prominent supraglenoid tubercle (tuberculum supraglenoidalis) in the present observation is projected cranially and distal to the incisura scapulae which was similar and dissimilar with horse and cattle respectively (Sisson et al.). Two muscular ridges in the infraspinous fossa (fossa infraspinata) are fanned out from the ventral angle.

Medial (costal) surface of scapula. In the present study, the deep subscapular fossa (fossa subscapularis) like horse and human (Sisson et al.) is divided into a larger triangular caudal fossa and a smaller cranial fossa which provides an attachment for the subscapularis muscle. The cranial fossa is originated due to presence of a raised column in subscapular fossa and it is convex towards cranial margin. Representation of facies serrata is more or less rough. The supraglenoid tuberosity (cavitas glenoidalis) has the coracoid process which is represented by a caudal ridge.

Ventral angle of scapula. Ventral angle of scapula articulated with humerus by glenoid cavity of scapula and head of humerus. The elongated shaped glenoid cavity (cavitas glenoidalis) is in cranio-caudal direction and concavity of glenoid cavity is divided into a large medial and a small lateral articular surface by a sagittal line which was similar with African elephant (Smuts \& Bezuidenhout).

Humerus (Figs. 5-7) . Humerus is important bones in the appendicular skeleton to bear whole body weight of elephant. The robust bone of humerus was a long bone which possesses a longest and heaviest in size and girth than the others bones of the fore limb. It situated obliquely downward and backward; forms shoulder joint above with the scapula and elbow joint below with the radius and ulna. It composed of a shaft (diaphysis), the corpus humeri and enlarged two extremities, proximal and distal epiphyses.

The proximal extremity of the humerus. A head (caput humeri), neck (collum humeri) and two tubercles (major and minor) represent the proximal extremity. The rounded head is situated in the caudo-medial portion of the extremity which is directed in cranio-caudal plane. The slightly constricted neck separates the head and shaft indistinctly. The major tubercle (tuberculum majus) is situated laterally to the head, which has smaller cranial part with large caudal part and extends cranially to the head. Minor tubercle (tuberculum minus), is located medially, distal to the medial margin of the head. The sulcus intertubercularis is situated medial to the cranial extremity of minor tubercle and lateral to the cranial part of major tubercle. For attachment of infraspinous muscle (facies musculi infraspinati), there is an oval area found lateral to major tubercle.

The body of the humerus, Corpus humeri. The crest of major tubercle (crista tuberculi majoris) is found cranially which is a prominent structure and vanish towards the middle of shaft. The rough line on the mediocaudal surface represents the crest of minor tubercle (crista tuberculi minoris). This line ends in a slight 


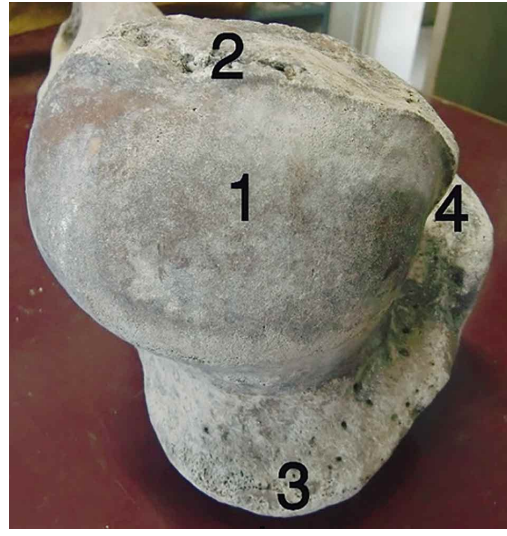

Fig. 5. Proximal end of humerus. $1=$ Head of humerus (Caput humeri), $2=$ Neck of humerus (Collum humeri), 3= Major tubercle (Tuberculum majus) and $4=$ Sulcus intertubercularis.

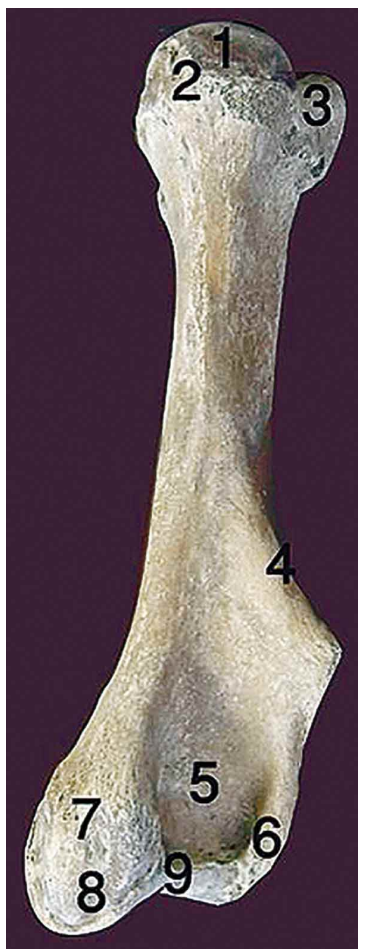

Fig. 6. Caudal aspect of left humerus. 1= Head of humerus (Caput humerus), $2=$ Neck of humerus (Collum humeri), $3=$ Major tubercle (Tuberculum majus), 4= Supracondylar crest (Crista supracondylaris lateralis), $5=$ Olecranon fossa (Fossa olecrani), $6=$ Lateral epicondyle (Epicondylus laterialis), $7=$ Medial epicondyle (Epicondylus medilaris), $8=$ Medial condyle (Condylus medialis) and $9=$ Trochlea (Trochlea humeri).

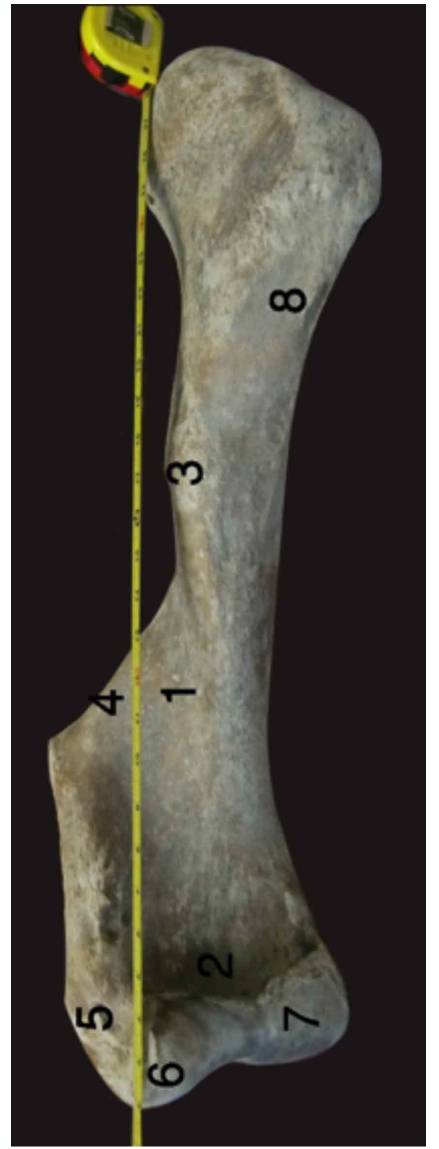

Fig. 7. Craniolateral view of left humerus. 1= Musculospiral groove (Sulcus musculi brachialis), 2= Radial fossa (Fossa radialis), 3= Deltoid tuberosity (Tuberositas deltoidea), $4=$ Supracondylar crest (Crista supra condylaris lateralis), 5= Lateral epicondyle (Epicondylus laterialis), 6= Lateral condyle (Condylus laterialis), $7=$ Medial condyle (Condylus medialis) and $8=$ Tuberositas teres major (Teres major tuberosity). rounded area, known as teres major tuberosity (tuberositas teres major) which is either a slightly elevated or depressed area. The nutrition foramen of shaft in the study is located distally to it, usually located in the caudal which was similar to sheep (Sisson et al.) and dissimilar to cattle (McLeod et al.), where the nutrient foramen was located at distal third of the lateral surface of humerus. In the body of humerus, each of the tubercles presents ridges for muscular attachment. In the proximal third of the shaft, represents the prominent deltoid tuberosity (tuberositas deltoidea), which is actually an indistinct rough elongated area which was dissimilar with cattle (Sisson et al.) and sheep (Sisson et al.). The deeper musculospiral groove is present in the lateral portion of the shaft. This was in agreement with the reports of Siddiqui et al. (2008) in Black Bengal goat.

The distal extremity of humerus, Condylus humeri. A sagittal groove divides the trochlea into a smaller medial portion and a larger lateral portion. The massive size of lateral epicondyle (epicondylus lateralis) lies just above the condyle which accommodate a number of foramina. The musculospiral groove is limited by the lateral supracondyler crest (crista supracondylaris lateralis) at the caudal surface of the shaft. The olecranon fossa (fossa olecrani) bounded by two epicondyles caudally which has gain shallow fossa which was similar in Black Bengal goat (Siddiqui et al.). The medial epicondyle (epicondylus medialis) is very small than the lateral one and located caudoproximally to this condyle. The radial fossa (fossa radialis) is on the cranial aspect and much concave laterally which was agreement of in cattle (Sisson et al.) and in dog these two fossa often communicate each other through a large supratrochlear foramen (Miller et al., 1964).

Radius and Ulna (Fig. 8). Twin bones of forearm of skeleton are radius and ulna which are faintly curved. Two bones formed elbow joint with the humerus above and carpal joint with the carpal bones below. The attachment between ulna and radius occurs in such a way, the radius articulates craniomedially with the ulna in the proximal part. But the shaft spirals laterally over the cranial surface of the ulna to articulate distally with the medial aspect of the ulna.

Radius. The radius gets two attachments proximally, one with the humerus and another with ulnar medial surface. It articulates with the carpal bones distally. Radius has two extremities (proximal and distal) and an intervening shaft or body. The proximal extremity is smaller and the distal extremity is larger and expanded. The radius is curved in a lateral direction along its longitudinal axis. In the proximal surface of the head of the radius, fovea capitis radii, a triangular articular surface is present for articulation with humerus. The neck, collum radii, is the constricted segment 


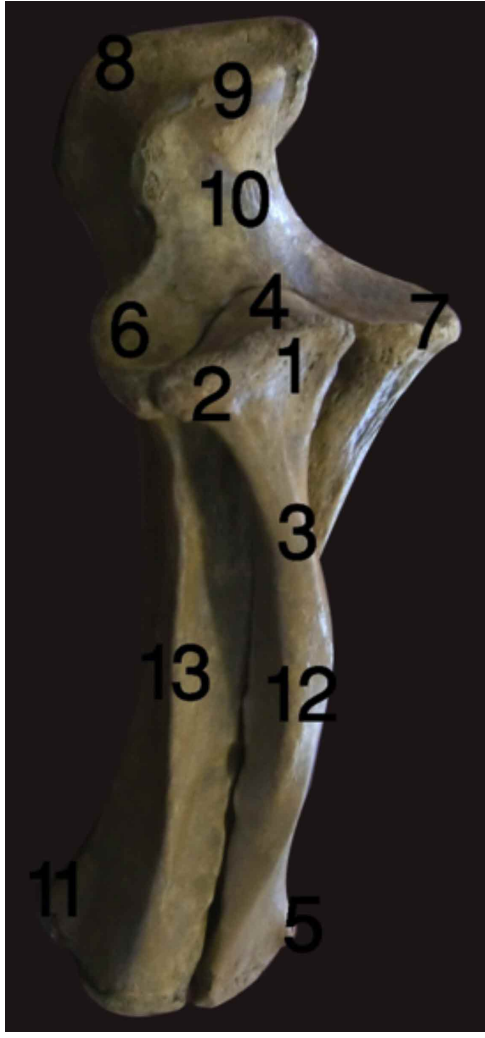

Fig. 8. Right radius-ulna. $1=$ Caput radii, $2=$ Neck (Collum radii), $3=\mathrm{Ra}-$ dial tuberosity (Tuberositas radii), $4=$ Fovea capitis radii, $5=$ Processus styloideus radii, $6=$ Processsus coronoideus lateralis, $7=$ Processsus coronoideus medialis, $8=$ Tuber olecrani, $9=$ Processsus anconeus, $10=$ Incisura trochlearis, $11=$ Processsus styloideus ulnae, 12= Shaft (Corpus radii) and $13=$ Shaft $($ Corpus ulnae $)$.

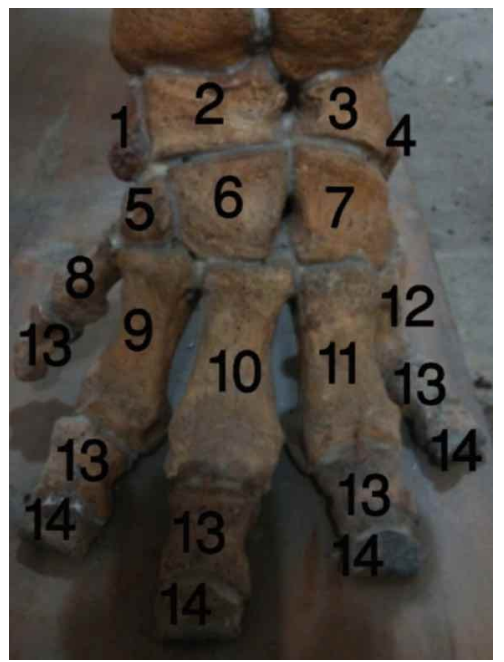

914 directly below the head. The neck presents an irregular surface for attachment with ulna in its caudal part. At cranial surface of the upper part, radial tuberosity (tuberositas radii) is rough for muscular attachment. Rough and irregular neck is situated caudally for attachment to the ulna. The shaft (corpus radii) is bilaterally compressed. Medially the shaft is concave and rough but lateral convex surface had a blur appearance of longitudinal ridge. The ridge is started from the cranial margin. Near the distal epiphysis, the caudal surface of the shaft increases in width. The distal extremity is irregularly triangular with the base directed caudally and this is the largest part of this bone. A number of foramina occurred in this portion. An oval articulation surface for ulnar attachment is found distally to the epiphysis. Processsus styloideus radii is represented by 2 rough convexities, separated from each other by a sight depression.

Ulna.The ulna is larger and longer than the radius having two extremities along with a body for descriptive purposes. Proximally, the olecranon is reached beyond the radius. The tuber olecrani was massive, especially caudolaterally. A broad arched dorsal surface of the olecranon process narrowed towards anconeus process (proccessus anconeus). There were a number of foramina in the dorsal surface of the olecranon. Below the tuber olecrani the bone compressed bilaterally and this forms a narrow caudal margin of the shaft. Trochlear notch (incisura trochlearis) faces cranially with its wider proximal part. The trochlear notch is continued distally by the medial and lateral portions of the coronoid processes to form a concave surface for articulation. The proximally placed anconeus process is wide and rounded in shape.

Cranially the shaft; corpus ulnae is flattened, proximally it is triangular shape and distally it seems almost square in shape. The cranial surface of ulna is roughened to aid articulation with radius extending from the proximal end in a distomedial direction. Proximally, a deep concave area; incisura radialis is present and an articular surface above it along the cranial surfaces of the coronoid processes. Lateral surface of the shaft is straight cranial margin and caudal margin is slightly sloped and narrowed down from the olecranon towards the shaft. The medial surface continues distally for rough area for the radius that widens towards the epiphysis. A longitudinal vascular groove is visible, which creates a bifurcation in the distal quarter. An irregular oval area was seen in the distal extremity of ulna for articulation with the radius. The ulnar carpal bone and the accessory carpal bone also articulate with the distal extremities of ulna. Styloid process (processsus styloideus ulnae) was caudally under the epiphyseal line and got a shape of lateral prominence. Numerous foramina were present in the surface of the bone in this region.

In the Asian elephant of the present observation, the ulna extend up to the distal extremity of the radius, which was in agreement with the cattle (McLeod et $a l$.), sheep (Sisson et al.) and disagreement with the horse (Sisson et al.), where the ulna was fused at the proximal third of the radius. The styloid process was observed similar to African elephant (Smuts \& Bezuidenhout), cattle (Sisson et al.), which were however absent in horse (Baumel \& Getty). In the Asian and African elephant, the interosseous space was not present which was dissimilar observations were noted in cattle (Sisson et al.), in sheep (Sisson et al.) and there was only one proximal interosseous space was noted in the horse (Sisson et al.).

Fig. 9. Manus. $1=$ Radial carpal, $2=$ Intermediate carpal, $3=$ Ulnar carpal, $4=$ Accessary carpal, 5= Carpal II, 6= Carpal III, 7= Carpal IV, 8= Metacarpal I, 9= Metacarpal II, 10= Metacarpal III, 11= Metacarpal IV, 12= Metacarpal V, 13= Proximal Phalanges of digits I-V and 14= Middle Phanlanges of digits II-IV. 
Manus (Fig. 9). Carpal Bones. In the present study, the carpal bones of Asian elephant were eight in number, which were arranged in two rows, four in the proximal row and four in the distal row. The proximal row consists of the radial, intermediate, ulnar and accessory carpal bones, on the other hand, the distal row composed of carpal bones I-IV. The radial carpal was the most flattened bone in the proximal row. Proximally the bone was articulates with the radius, distally with second and third carpal bones and laterally with intermediate carpal bone. The Intermediate carpal bone was wedge shaped proximally articulate with radius and dorsolaterally an oblique continuation of this surface also articulate with the ulna and with the ulnar carpal bone. Also it articulates distally with the third carpal bones. Roughly triangular ulnar carpal bone is the largest bone in the proximal row and it situated on the lateral side. Its palmar side had large oval articular facet occurs for the articulation with accessory carpal bone. Proximally it articulated with ulna and distally fourth carpal bone. It had a small elongated facet facing dorsopalmarly articulated with the fifth metacarpal bone. The accessory carpal bone articulated with the palmar surface of ulnar carpal and with the ulna. The rest of the non-articular surfaces were rough and contained numerous small vascular foramina. First carpal bone was present in Asian elephant fore limb, but in our study we lost during excavation of the deep burial of skeleton. The first carpal bone of the distal row was a flattened roughly quadrilateral bone. Its medial surface was more or less flattened and rough and the lateral surface was more concave containing numerous nutrient foramina (Smuts $\&$ Bezuidenhout). Second carpal bone was roughly triangular bone having a blunt palmar projection. Laterally it articulated with the third carpal bone, proximally with the medial part of the radial carpal and intermediate carpal. Distally joined with second metacarpal bone. Square sized third carpal communicated proximally with mainly intermediate carpal and distally articulated with second and third metacarpal bone. The fourth carpal bone that form the lateral component of distal row, articulated proximally with ulnar carpal bone and distally with metacarpal III, IV and V. The comparative size of the distal carpal bones were IV > III > II > I (from the largest to the smallest). This was agreement in horse (Sisson et al.), and disagreement in cattle and sheep, where the proximal row consist of radial, intermediate, ulnar, and accessory carpal and the distal row were consisted of two due to first carpal bone absent, second and third carpal fused to third carpal and fourth one was single (Sisson et al.).

Metatcarpal bones. There were five metacarpal bones lying between the carpal bones and the digits. The relative size of the metacarpal bones were III $>$ IV $>$ II $>$ V $>$ I with the length $13 \mathrm{~cm}, 12 \mathrm{~cm}, 11.5 \mathrm{~cm}, 10 \mathrm{~cm}$ and $7.5 \mathrm{~cm}$ respectively. Metacarpal I, II, III and IV were the most oblique and metacarpal V was the most vertical. In Black Bengal goat, only the large metacarpal bone was present which consist of III and IV. Other metacarpal bones were absent (Siddiqui et $a l$.$) . The small metacarpal bone (metacarpal-v) was present$ in cattle (McLeod et al.). This was disagreement in horse, where three metacarpal bones were present in which the third was fully developed and the second and fourth were much fused with the third and commonly known as small metacarpal or "splint bones". First and fifth were absent (Sisson et al.).

Digits. In our study, Asian elephant consists of five digits and digit I and V bearded one phalanx and two phalanges respectively. In Asian elephant, digit II, III and IV consist of two phalanges but in African elephant digit II, III and IV bearded three phalanges in each but digit $\mathrm{V}$ consists of two phalanges (Smuts \& Bezuidenhout). Variation in number of phalanx may be due to loss of small bones during the time of collection or may be species difference. Also, considerable confusion marks the descriptions of the phalanges. We believe this to be due to the atypical position and possible function of the distal phalanges of digits 2-4. They do not articulate with the middle phalanges, are relatively very small and are attached to the respective nails (Güßgen, 1988). Digits three and four were larger than the others. Digits I and V were vertical and digit II, III and IV were horizontal. The functional consequence of the shape of the manus was that digits II, III and IV act like three supports of a tripod, in contrast to the more unified column of the manus (Miller et al., 2008). This was disagreement in cattle (Sisson et al.) and disagreement in horse (Sisson et al.) where, only fully developed two digits (III and IV) and one digit was found in forelimb respectively. The proximal sesamoid bones are found in pairs which articulate with each other, located on the metacarpal-phalangeal articulation. A single flattened sesamoid bone is found the same position on metacarpal I. But, the sesamoid bones was present in Asian elephant fore limb as like as African elephant forelimb, but in our study we lost due to small size sesamoid bones during excavation of the deep burial of skeleton.

\section{CONCLUSION}

For a concise anatomical knowledge and helping tools for radiographic interpretation the above mentioned information regarding forelimb bone of Asian elephant will pave the pathway and guide us with a better understanding of the relevant anatomical parameters. This interpretation can be put impact directly to other captive elephants to enhance their veterinary care, and to facilitate communication among veterinarians regarding forelimb and foot disease recognition, disease severity, and treatment options. This will show new horizon for the veterinary anatomist for research. 


\section{ACKNOWLEDGEMENTS}

The authors are grateful to the Chief Conservator of Forest, Bangladesh and the authority of Bangabandhu Sheikh Mujib Safari Park, Dulahazra, Cox’s Bazar, Bangladesh for their kind cooperation.

AHASAN, A. M. S. L.; QUASEM, M. A.; RAHMAN, M. L.; HASAN, R. B.; KIBRIA, A. S. M. G. \& SHIL, S. K. Macroanatomía de los huesos del miembro torácico de un elefante asiático (Elephas maximus). Int. J. Morphol., 34(3):909917, 2016.

RESUMEN: En el Museo de Anatomía de la Universidad de Veterinaria y Ciencias de Animales de Chittagong fueron estudiados los huesos del miembro torácico de un esqueleto preparado de un elefante asiático (Elephas maximus), hembra adulta, para analizar su morfología y estructura. El ángulo entre el margen caudal de la escápula y el margen caudal del húmero era de aproximadamente $123^{\circ}$. La escápula, húmero y los huesos del antebrazo (en particular la ulna) eran huesos macizos. Los huesos de las manos eran cortos y relativamente pequeños. El margen dorsal de la escápula se extendía desde el nivel de la porción proximal de la primera costilla para la parte media de la sexta costilla. El ángulo ventral de la escápula está articulado con el húmero por la cavidad glenoidea (cavitas glenoidalis), de forma alargada, de la escápula y la cabeza del húmero (caput humeri). El principal tubérculo (tuberculum majus) del húmero estaba situado lateralmente a la cabeza, que tenía una parte craneal pequeña y una mayor parte caudal, extendiéndose cranealmente en la cabeza. La cresta del tubérculo menor (tuberculum minus) estaba presente como la línea áspera sobre la superficie mediocaudal del húmero que termina en una pequeña zona deprimida o elevada, conocida como tuberosidad redonda mayor (tuberositas teres major). La cresta supracondilar lateral (crista supra condylaris lateralis) en la superficie caudal del eje limita la ranura músculo-espiral en el húmero. El radio y la ulna son huesos gemelos del antebrazo y la unión entre la ulna y el radio se produce de tal manera, que el radio articula, craneal y medialmente, con la ulna en la porción proximal. Pero el eje en espiral está ubicado lateralmente sobre la superficie craneal de la ulna para articular distalmente con la cara medial de la ulna. Se identificaron 8 huesos del carpo, 5 metacarpianos y 5 dígitos. El tamaño comparativo de las porciones proximal y distal de los huesos del carpo fue ulna > radial > Intermedio > carpiano accesorio y IV > III > II $>\mathrm{I}$, respectivamente. Las longitudes graduales de los huesos metacarpianos eran III > IV > II > V > I. Dígitos I y V eran verticales y dígitos II, III y IV fueron horizontales

PALABRAS CLAVE: Elephas maximus; Escápula; Humero; Radio; Ulna; Mano.

\section{REFERENCES}

Alexander, R. McN.; Maloiy, G. M. O.; Hunter, B.; Jayes, A. S. \& Nturibi, J. Mechanical stresses in fast locomotion of buffalo (Syncews coffer) and elephant (Loxodonta africana). J. Zool., 189(2):135-44, 1979.

Clauss, M.; Loehlein, W.; Kienzle, E. \& Wiesner, H. Studies on feed digestibilities in captive Asian elephants (Elephas maximus). J. Anim. Physiol. Anim. Nutr. (Berl.), 87(3-4):16073, 2003.

Gambaryan, P. P. \& Hardin, H. How Mammals Run: Anatomical Adaptations. New York, J. Wiley, 1974.

Grzimek, B. Grzimeks Enzyklopädie. Band IV. Kindler, Verlag, 1987.

Güßgen, B. Vergleichende Zusammenstellung der Literaturbefunde über die Anatomie des Indischen und Afrikanischen Elefanten als Grundlage für tierärztliches Handeln. Dissertation. Hannover, Tierärztliche Hochschule Hannover, 1988.

Hildebrand, M. \& Hurley, J. P. Energy of the oscillating legs of a fast-moving cheetah, pronghorn, jackrabbit, and elephant. $J$. Morphol., 184(1):23-31, 1985.

Howell, A. B. Speed in Animals: Their Specialization for Running and Leaping. New York, Hafner Publishing Co., 1944.

Hutchinson, J. R.; Famini, D.; Lair, R. \& Kram, R. Biomechanics: Are fast-moving elephants really running? Nature, 422(6931):493-4, 2003.

Keele, M. \& Lewis, K. Asian elephant (Elephas maximus). North American Regional Studbook. Portland, Oregon Zoo \& American Zoo and Aquarium Association, 2005.

Mariappa, D. Anatomy and Histology of the Indian Elephant. Oak Park, Indira Publishing House, 1986.

McLeod, W. M.; Trotter, D. M. \& Lunb, J. W. Bovine Anatomy. Minneapolis, Burgess Publishing Company, 1958.

Miller, C. E.; Basu, C.; Fritsch, G.; Hildebrandt, T. \& Hutchinson, J. R. Ontogenetic scaling of foot musculoskeletal anatomy in elephants. J. R. Soc. Interface, 5(21):465-75. 2008.

Miller, M. E.; Christensen, G. \& Evans, H. E. Anatomy of the Dog. $9^{\text {th }}$ ed. Philadelphia, W. B. Saunders, 1964.

Muybridge, E. Animals in Motion. An Electro-Photographic Investigation of Consecutive Phases of Animal Progressive Movements. London, Chapman \& Hall, 1899.

Nowak, R. M. Walker's Mammals of the World. $6^{\text {th }}$ ed. Baltimore, Johns Hopkins University Press, 1999. 
AHASAN, A. M. S. L.; QUASEM, M. A.; RAHMAN, M. L.; HASAN, R. B.; KIBRIA, A. S. M. G. \& SHIL, S. K. Macroanatomy of the bones of thoracic limb of an Asian Elephant (Elephas maximus). Int. J. Morphol., 34(3):909-917, 2016.

Nzalak, J. O.; Eki, M. M.; Sulaiman, M. H.; Umosen, A. D.; SaLami, S. O.; Maidawa, S. M. \& Ibe, C. S. Gross anatomical studies of the bones of the thoracic limbs of the Lion (Panthera leo). J. Vet. Anat., 3(2):65-71, 2010.

Siddiqui, M. S. I.; Khan, M. Z. I.; Moonmoon, S.; Islam, M. N. \& Jahan, M. R. Macro-anatomy of the bones of the fore limb of Black Bengal Goat (Capra hircus). Bangl. J. Vet. Med., 6(1):5966, 2008.

Sisson, S.; Grossman, J. D. \& Getty, R. Sisson and Grossman's The Anatomy of the Domestic Animals. $5^{\text {th }}$ ed. Philadelphia, Saunders, 1975. pp.2019-66.

Smuts, M. M. \& Bezuidenhout, A. J. Osteology of the thoracic limb of the African elephant (Loxodonta africana). Onderstepoort. J. Vet. Res., 60(1):1-14, 1993.

Tietze, A. Ueber den architektonischen Aufbau des Bindegewebes in der menschlichen Fußsohle. Bruns' Beiträge Zur Klinischen Chirurgie, 123:493-506. 1921.

Virchow, H. Hand und Fuss des Elefanten, nach Form zusammengesetzt. Berlin, Sitzungsberichte der Gesellschaft der Naturforschenden Freunde Berlin, 1910. pp.77-87.

Weissengruber, G. E. \& Forstenpointner, G. Musculature of the crus and pes of the African elephant (Loxodonta africana): insight into semiplantigrade limb architecture. Anat. Embryol. (Berl.)., 208(6):451-61, 2004.

Weissengruber, G. E.; Fuss, F. K.; Egger, G.; Stanek, G.; Hittmair, K. M. \& Forstenpointner, G. The elephant knee joint: morphological and biomechanical considerations. J. Anat., 208(1):59-72. 2006.

Williams, P. L. Gray's anatomy. London Churchill Livingstone, 1980.

\section{Correspondence to:}

Dr. A. S. M. Lutful Ahasan

Associate Professor

Dept. of Anatomy and Histology

Chittagong Veterinary \& Animal Sciences University

Khulshi

Chittagong

BANGLADESH

Cell phone: 008801819821760

Tel: +88-031-659093. Ext-141

Fax: +880-031-659620

Email: lutfulahasan19@yahoo.com lutfulahasan29@gmail.com

Received: 03-02-2016

Accepted: 20-06-2016 